\title{
Bioactivity of glycolipopeptide cell-bound biosurfactants against skin pathogens
}

\author{
Vecino, X.1,2*, Rodríguez-López, L. ${ }^{2}$, Ferreira, D. ${ }^{1}$, Cruz, J.M. ${ }^{2}$, Moldes, A.B. ${ }^{2}$, \\ Rodrigues, L.R. ${ }^{1}$
}

\author{
${ }^{1}$ CEB-Centre of Biological Engineering, University of Minho, 4710-057 Braga, \\ Portugal.
}

${ }^{2}$ Chemical Engineering Department, School of Industrial Engineering (EEI)- Módulo Tecnológico Industrial (MTI), University of Vigo, Campus As Lagoas-Marcosende, 36310 Vigo, Spain.

*Author corresponding: xanel.vecino@,ceb.uminho.pt; xanel.vecino@uvigo.es. 


\section{ABSTRACT}

The antimicrobial and anti-adhesive activities of the cell-bound biosurfactants, produced by Lactobacillus pentosus (PEB), characterized as glycolipopeptide macromolecules, were evaluated against several microorganisms present in the skin microflora, envisaging its potential use as a "natural" ingredient in cosmetic and personal care formulations. Their performance was compared with another cell-bound biosurfactants also characterized as glycolipopeptides produced by Lactobacillus paracasei $(\mathrm{PAB})$. At concentrations of $50 \mathrm{mg} / \mathrm{mL}$, the $\mathrm{PEB}$ showed an important antimicrobial activity against Pseudomonas aeruginosa (85\% when extracted with phosphate buffer (PB) and 100\% when extracted with phosphate buffer saline (PBS)), Streptococcus agalactiae (100\% for both extracts), Staphylococcus aureus (67\% when extracted with PBS and 100\% when extracted with PB), Escherichia coli (72\% when extracted with PB and $89 \%$ when extracted with PBS), Streptococcus pyogenes (about $85 \%$ for both extracts) and Candida albicans (around $70 \%$ for both extracts), comparable with that obtained for the PAB. However, at lower concentrations the PAB exhibited in general higher antimicrobial activities. Biosurfactants produced by both microorganisms also showed significant anti-adhesive properties against all the microorganisms under study, except for E. coli and C. albicans (less than 30\%). Overall, these cell-bound biosurfactants could be used as potential antimicrobial and anti-adhesive agents in cosmetic and pharmaceutical formulations.

Keywords: Lactobacilli; antimicrobial; anti-adhesive. 


\section{INTRODUCTION}

Human skin is the largest tissue of the human body and is composed by resident, temporarily resident and transient microbial species, being the Gram-positive bacteria from the genera Propionibacterium, Staphylococcus, Micrococcus, Corynebacterium and Acinetobacter the main resident microorganisms [1]. Among the Staphylococcus, Staphylococcus aureus is a common transient specie, which causes skin infections, whereas Staphylococcus epidermidis is a resident bacteria of skin microflora that protects the human skin from certain types of infection [2].

The microflora generates inhibitory substances, namely bacteriocins, enzymes and low molecular weight inhibitors, which contribute to keep the balance of resident microbial populations, and prevent its colonization by pathogens [1]. Beauty and personal care products incorporate some anti-bacterial preservatives towards harmful microorganisms as triclosan, methylparaben or bronopol, among others. Although these anti-bacterial preservatives are currently used, there is a growing demand for cosmetics free of synthetic preservatives [3,4]. In this sense, biosurfactants from lactic acid bacteria (LAB), which are "Generally Recognized As Safe" (GRAS) by the American Food and Drug Administration (FDA), are natural compounds that exhibit antimicrobial activity and cleaning abilities that could therefore be used as an alternative to the chemically synthetized preservatives [5-8]; but also because at the same time they are non-toxic, biodegradable and environmentally friendly [9-11]. For instance, interesting results have been reported when using a rhamnolipid formulation (25\% of biosurfactant and $75 \%$ of water) as an antimicrobial and surface-active agent in soak toothbrush holders, hairbrushes and infant plastic toys [12].

Synthetic surfactants can cause skin irritation and allergic reactions by interaction with proteins such as keratin (cytoskeletal proteins) or collagen and elastin (extracellular matrix proteins); also they promote the removal of lipids from the epidermal surface and 
affect the living cells in the skin [13]. Contrarily, biosurfactants are composed of lipid and proteins that are compatible with the skin cells membrane $[14,15]$.

The aim of the current study is to evaluate the antimicrobial and anti-adhesive activities of the cell-bound biosurfactants produced by Lactobacillus pentosus against skin pathogens, in comparison with the cell-bound biosurfactants produced by Lactobacillus paracasei both characterized as glycolipopeptide macromolecules. The corresponding biosurfactants were extracted using two different methodologies and both extracts were evaluated.

\section{MATERIALS AND METHODS}

\subsection{Strains and standard culture conditions for biosurfactant production}

L. pentosus CECT-4023T (ATCC-8041) was obtained from the Spanish Type Culture Collection (CECT) (Valencia, Spain), while L. paracasei was isolated from a Portuguese dairy industry [5].

Both strains were grown for $24 \mathrm{~h}$ in Petri dishes containing complete medium, so-named by its inventors (de Man, Rogosa and Sharpe), MRS Agar, at $31^{\circ} \mathrm{C}$ and $37^{\circ} \mathrm{C}$, respectively. Inocula were prepared by solubilizing all cells from plates with $5 \mathrm{~mL}$ of culture media. Then, cells were incubated at $150 \mathrm{rpm}$, at the optimum temperature for each microorganism in $250 \mathrm{~mL}$ Erlenmeyer flasks containing the rest of culture media (100 $\mathrm{mL}$ as total volume).

\subsection{Production and extraction of the biosurfactants from Lactobacilli strains}

The fermentation medium for L. pentosus contained $11 \mathrm{~g} / \mathrm{L}$ of glucose and $18 \mathrm{~g} / \mathrm{L}$ of xylose. This strain is a hetero-fermentative facultative lactic acid bacterium able to metabolize pentoses, whereas the fermentation medium for L. paracasei, a homofermentative strain, was formulated with $33 \mathrm{~g} / \mathrm{L}$ of glucose. Both media were 
supplemented with $10 \mathrm{~g} / \mathrm{L}$ of corn steep liquor and $10 \mathrm{~g} / \mathrm{L}$ of yeast extract as nitrogen source, sterilized $\left(121^{\circ} \mathrm{C}\right.$ during $\left.15 \mathrm{~min}\right)$ and used directly as fermentation media.

The fermentations were carried out in a 2 L Applikon fermenter, at $200 \mathrm{rpm}$, with a working volume of $1.5 \mathrm{~L}$, at $31^{\circ} \mathrm{C}$, during $48 \mathrm{~h}$ for L. pentosus and at $37^{\circ} \mathrm{C}$, during $24 \mathrm{~h}$, for L. paracasei. The $\mathrm{pH}$ was adjusted to 6 for both strains.

Afterwards, the fermentation medium was centrifuged, the biomass was washed twice with distilled water and re-suspended in $250 \mathrm{~mL}$ of phosphate buffer saline (PBS) (10 $\mathrm{mM} \mathrm{KH} \mathrm{KH}_{4} / \mathrm{K}_{2} \mathrm{HPO}_{4}$ with $\left.150 \mathrm{mM} \mathrm{NaCl}\right)$ or phosphate buffer (PB) $(10 \mathrm{mM}$ $\mathrm{KH}_{2} \mathrm{PO}_{4} / \mathrm{K}_{2} \mathrm{HPO}_{4}$ without salt). The biomass/liquid ratio used for the extraction was $6: 1$. The extraction with PBS was carried at room temperature $\left(25^{\circ} \mathrm{C}\right)$ during $2 \mathrm{~h}$ at $150 \mathrm{rpm}$ [16]; whereas the extraction with $\mathrm{PB}$ was established at $65^{\circ} \mathrm{C}$ during $1.5 \mathrm{~h}$ at $150 \mathrm{rpm}$ according to a previous study [17]. The solutions containing the cell-bound biosurfactants were dialyzed against demineralized water at $4^{\circ} \mathrm{C}$ in a Cellu-Sep $\mathrm{C}$ membrane (molecular weight cut-off 6000-8000 Dalton; Membrane Filtration Products, Inc., USA) for $48 \mathrm{~h}$, and then the biosurfactants were lyophilized using a lyophilizer CHRIST ${ }^{\circledR}$ Alpha 1-4 LD plus (Germany).

Four different cell-bound biosurfactant extracts were obtained depending on the Lactobacilli strain and the methodology used for their extraction, namely the biosurfactants produced by L. pentosus (PEB) extracted with PBS and PB; and the biosurfactants obtained from L. paracasei (PAB) extracted with PBS and PB.

\subsection{Cell-bound biosurfactants characterization}

Different surfactant properties such as critical micellar concentration (CMC) and surface tension reduction (ST), as well as protein, carbohydrate and lipid contents of the cellbound biosurfactants were evaluated following the protocols established in previous works $[18,19]$. Therefore, total carbohydrate content in the biosurfactant extracts was determined by the phenol-sulfuric acid method using D-glucose as a standard [20]; total 
protein content was calculated by multiplying the total nitrogen content of the biosurfactant extracts by a conversion factor of 6.25 [21] and lipid content was analyzed by Gas Chromatography coupled to a Mass Spectrometer (GC-MS-MS).

The fatty acid methyl esters (FAMEs) separation was performed on a Model Scion 451 GC (Bruker) equipped with a PTV 1019 universal capillary injector $(1 \mu \mathrm{L}$ of sample was injected using a splitless mode) and a DB-WAX column (30 m long, $0.25 \mathrm{~mm}$ i.d., 0.25 $\mu \mathrm{m}$ film thickness) using an oven temperature gradient as follows: $50^{\circ} \mathrm{C}$ for $2 \mathrm{~min}$, then raised to $220^{\circ} \mathrm{C}$ at a rate equal to $4{ }^{\circ} \mathrm{C} / \mathrm{min}$ and then maintained for more $15 \mathrm{~min}$. Helium was used as carrier gas at a constant flow rate of $1 \mathrm{~mL} / \mathrm{min}$. The temperature of both injector inlet and the transfer line of the detector was set at $240^{\circ} \mathrm{C}$.

The mass spectra were obtained using a mass-selective detector under electron impact ionization at a voltage of $70 \mathrm{eV}$ and data were acquired over an $\mathrm{m} / \mathrm{z}$ range $50-400$. The software used to process the peak areas was MS Data Review (version 8.1).

FAMEs were identified using a mass spectra library supplied with the GC-MS-MS system and by comparison of retention times and mass spectra of a FAME standard mix (Supelco 37 Component FAME Mix: $10 \mathrm{mg} / \mathrm{mL}$ of the FAME reference standard mix in methylene chloride, Sigma-Aldrich) injected under the same conditions.

\subsection{Strains and standard culture conditions for antimicrobial and anti-adhesive assays}

The following strains, kindly provided by the Faculty of Pharmacy, University of Porto (Portugal), were used in the antimicrobial and anti-adhesive assays: Escherichia coli, Pseudomonas aeruginosa, Staphylococcus aureus, Staphylococcus epidermidis, Streptococcus agalactiae, Streptococcus pyogenes and Candida albicans. These strains were grown overnight in Trypticase Soy Broth (TSB) medium at $37^{\circ} \mathrm{C}$ in aerobic conditions. The composition of TSB medium was: $17 \mathrm{~g} / \mathrm{L}$ casein peptone (pancreatic), 3 $\mathrm{g} / \mathrm{L}$ soya peptone (papain digest.), $5 \mathrm{~g} / \mathrm{L}$ sodium chloride, $2.5 \mathrm{~g} / \mathrm{L}$ di-potassium hydrogen phosphate and $2.5 \mathrm{~g} / \mathrm{L}$ glucose. 
All strains were stored at $-80^{\circ} \mathrm{C}$ in appropriate medium supplemented with glycerol $(20 \%$ (v/v)) until use.

\subsection{Antimicrobial assay}

The antimicrobial activity of the biosurfactants from Lactobacillus strains against skin pathogens was determined according to the procedure described elsewhere [5]. Briefly, a micro-dilution method in 96-well flat-bottom plastic tissue culture plates (Orange Scientific, Belgium) was used. A $125 \mu \mathrm{L}$ of sterile double strength growth TSB medium was placed in the well 1 of the microplate, together with $125 \mu \mathrm{L}$ of biosurfactant solution at $100 \mathrm{mg} / \mathrm{mL}$. Serially, $125 \mu \mathrm{L}$ from well 1 was transferred to the subsequent wells, adding $125 \mu \mathrm{L}$ of sterile single strength growth TSB medium. After the consecutive dilutions the biosurfactant concentration in the wells ranged between $50-0.10 \mathrm{mg} / \mathrm{mL}$. Following, $2.5 \mu \mathrm{L}$ of a pre-culture of the evaluated microorganism, grown overnight in TSB medium at $37^{\circ} \mathrm{C}$ and diluted to an optical density of 0.6 , where added to each well, except well 11, that was used as negative control, containing only TSB medium (125 $\mu \mathrm{L})$. In addition, well 12 was used as positive control, containing only TBS medium (125 $\mu \mathrm{L})$ and the microorganism inoculum $(2.5 \mu \mathrm{L})$.

The microplates were covered, incubated for $48 \mathrm{~h}$ at $37^{\circ} \mathrm{C}$ and the optical density of each well were measured at $600 \mathrm{~nm}$ in a microplate reader (Biotech Synergy HT). The growth inhibition percentages at different biosurfactant concentrations for each pathogen were calculated following Equation 1:

$$
\text { Growth inhibition }_{c}(\%)=\left[1-\frac{\left(O D_{c}\right)}{\left(O D_{0}\right)}\right] \times 100 \quad \text { Equation (1) }
$$

where $\mathrm{OD}_{\mathrm{c}}$ represents the optical density of the well with a biosurfactant concentration $\mathrm{c}$ and $\mathrm{OD}_{0}$ is the optical density of the control well (without biosurfactant). Triplicate assays were performed at all biosurfactant concentrations for each strain. 


\subsection{Anti-adhesive assay}

The anti-adhesive activity of biosurfactants from Lactobacillus strains was tested against the same pathogens described in the antimicrobial assay. Wells of a sterile 96-well flatbottom plastic tissue culture plate were filled with $200 \mu \mathrm{L}$ of crude biosurfactant solution in PBS or PB following the methodology reported elsewhere [5]. Several biosurfactant concentrations were tested ranging from 0.02 to $25 \mathrm{mg} / \mathrm{mL}$. The plate was incubated for $18 \mathrm{~h}$ at $4^{\circ} \mathrm{C}$ and subsequently washed twice with PBS or PB. Control wells contained only PBS or PB. A $200 \mu \mathrm{L}$ aliquot of a washed bacterial suspension in PBS or PB, adjusted to an optical density of 0.6 , was added to each well and incubated for $24 \mathrm{~h}$ at $4^{\circ} \mathrm{C}$. Unattached microorganisms were removed by washing the wells three times with PBS or PB; whereas the attached microorganisms were fixed with $200 \mu \mathrm{L}$ of $99 \%$ methanol per well during $15 \mathrm{~min}$, then the plates were emptied and left to dry. Afterwards, the plates were stained for 5 min with $200 \mu \mathrm{L}$ of $2 \%$ crystal violet per well (used for Gram staining). The excess of stain was rinsed out by placing the plate under running tap water. Subsequently, the plates were air-dried, the dye bound to the adherent microorganisms was re-solubilized with $200 \mu \mathrm{L}$ of $33 \%$ (v/v) glacial acetic acid per well and the optical density was measured at $595 \mathrm{~nm}$. The microbial inhibition percentages at different biosurfactant concentrations for each microorganism were determined according to Equation 2:

$$
\text { Microbial inhibition }_{c}(\%)=\left[1-\frac{\left(O D_{c}\right)}{\left(O D_{0}\right)}\right] \times 100 \quad \text { Equation (2) }
$$

where $\mathrm{OD}_{\mathrm{c}}$ represents the optical density of the well with a biosurfactant concentration $\mathrm{c}$ and $\mathrm{OD}_{0}$ is the optical density of the control well (without biosurfactant). Triplicate assays were performed at all biosurfactant concentrations for each strain.

\section{RESULTS AND DISCUSSION}


Biosurfactants are promising macromolecules for cosmetic, pharmaceutical or biomedical uses $[9,11,22]$. They are biocompatible molecules that reduce the surface tension in aqueous solutions allowing the solubilization of hydrophobic active principles. Comparing to their chemical counterparts, the biosurfactants exhibit a number of advantages and specifically for applications that involve contact with the skin, they could be regarded as prebiotic ingredients, protecting the skin as they prevent the growth of pathogenic microorganisms and stimulate the establishment of a beneficial microflora. In this work, the antimicrobial and anti-adhesive capacity of two different cell-bound biosurfactants produced by two probiotic Lactobacilli strains was studied. Additionally, it is remarkable that more than $90 \%$ of the biosurfactant-related works about theses biological activities refer that biosurfactants are produced extracellularly and only a few report the use of cell-bound biosurfactants. However, some of the cell-bound biosurfactants that have been reported are produced by probiotic bacteria and therefore, are quite interesting as they can potentially exhibit prebiotic properties [9].

Table 1 shows the composition of the biosurfactants herein studied that were extracted from the cell membrane using two different approaches. The biosurfactants extracted with PBS were found to possess a higher content in lipids than those extracted with PB, whereas the content in carbohydrates was higher in the extracts obtained using PB. Additionally, a higher protein content was found in the biosurfactants produced by $L$. paracasei mainly when these were extracted with PB. Regarding the Lactobacilli strains, L. paracasei produced biosurfactants with a lower content of lipids than those produced by L. pentosus.

In addition, Figure 1 shows the GC-MS spectra of the L. pentosus and L. paracasei biosurfactants illustrating their fatty acid profile. The biosurfactants were composed by C15 (myristic acid), C16 (palmitic acid), C17 (palmitoleic acid) and C18 (stearic, oleic, linoleic and $\alpha$-linoleic acids) fatty acid chains. A high percentage of C16 and C18 fatty 
acids was observed, being the most abundant the palmitic acid (22.1-43.9\%) and stearic acid (26.1-41.6\%). Moreover, differences in the fatty acids content were observed depending on the Lactobacilli strain and the methodology used for their extraction. For instance, the PEB contained a higher percentage of oleic acid (25.2-28.6\%) than the PAB (1.2-7.4\%); whereas palmitoleic acid was only present in the biosurfactants obtained from L. paracasei. Moreover, the biosurfactants extracted with PBS contained a higher percentage of stearic and oleic acids and a lower content in palmitic acid than those extracted with PB.

\subsection{Antimicrobial activity}

Figure 2 to Figure 4 show the antimicrobial activities of the four cell-bound biosurfactants evaluated against skin pathogenic: Gram-negative bacteria, Gram-positive bacteria and fungi, respectively.

In order to discuss the antimicrobial activities of the biosurfactant extracts, only the concentrations that showed an antimicrobial activity higher than $50 \%$ will be considered. It is interesting to notice that at the highest concentration assayed $(50 \mathrm{mg} / \mathrm{mL})$, the cellbound PEB exhibited $100 \%$ growth inhibition against S. agalactiae and about $70 \%$ against C. albicans (Figure 3c and Figure 4, respectively). Regarding the extraction method used, it was found that the biosurfactant produced by L. pentosus extracted with PBS possessed a higher antimicrobial activity against the Gram-negative microorganisms E. coli (89\%) (Figure 2a) and P. aeruginosa (100\%) (Figure 2b) as compared to the one extracted with PB (72\% and $85 \%$ respectively). Contrarily, the biosurfactants extracted with PB showed a higher antimicrobial activity against S. aureus (100\%) (Figure 3a) and S. pyogenes (87\%) (Figure 3d) as compared to the ones extracted with PBS $(67 \%$ and $83 \%$, respectively). In the case of $S$. agalactiae (Figure 3c) and C. albicans (Figure 4) the antimicrobial activity was $100 \%$ and $71 \%$, respectively, using PBS and PB 
extraction methods; while for $S$. epidermidis (Figure 3b) the values were lower than $50 \%$.

Regarding the antimicrobial properties of the biosurfactants from L. paracasei at the highest concentration tested $(50 \mathrm{mg} / \mathrm{mL})$, it was observed the same antimicrobial activity against E. coli, $P$. aeruginosa, S. epidermidis, S. agalactiae, S. pyogenes and C. albicans (all $100 \%$ ) by PAB extracted with PBS and PB; and only in the case of $S$. aureus the PAB extracted with PB exhibited $100 \%$ antimicrobial activity, whereas in PBS was $83 \%$. On the other hand, at a lower biosurfactant concentration $(25 \mathrm{mg} / \mathrm{mL})$, PAB generally showed different antimicrobial activities depending on the extraction method. The effect observed on $S$. aureus was in accordance with that noticed using the biosurfactants from L. pentosus. Indeed, for this pathogenic microorganism a better antimicrobial activity was found for the extracts obtained with PB (Figure 3a). As well, similar antimicrobial performance was observed against $S$. epidermidis at $25 \mathrm{mg} / \mathrm{mL}$ using PB (Figure 3b). On the other hand, the use of PBS rendered a highest antimicrobial effect in comparison with the extract obtained with PB against $S$ agalactiae (Figure 3c), S. pyogenes (Figure 3d) and C. albicans (Figure 4). However, in the case of E. coli it was found that the procedure used to extract the biosurfactants from $L$. paracasei did not affect its antimicrobial activity, contrarily to the extracts obtained from L. pentosus (Figure 2a). Based on these results, it can be speculated that the antimicrobial activity of the biosurfactants depend on the strain used for its production, regardless of being from the same genus, and also depend on the methodology used for their extraction.

Table 1S (see in the supplementary information) gathers information on the minimum doses of biosurfactants that led to antimicrobial activities higher than $50 \%$ or equal to $100 \%$. PEB, at concentrations of $25 \mathrm{mg} / \mathrm{mL}$, were able to reduced $50 \%$ the growth of $P$. aeruginosa, S. agalactiae and S. pyogenes, whenever extracted with PBS; whereas on $E$. coli, S. aureus and C. albicans, 50\% of growth inhibition was obtained at concentration 
of $50 \mathrm{mg} / \mathrm{mL}$. Moreover, at the same concentration $(50 \mathrm{mg} / \mathrm{mL}) 100 \%$ antimicrobial inhibition against $P$. aeruginosa and $S$. agalactiae was found.

Regarding the biosurfactant from L. pentosus extracted with $\mathrm{PB}$, it was found that a concentrations of $25 \mathrm{mg} / \mathrm{mL}$ could only reduce $50 \%$ the growth of $P$. aeruginosa and $S$. aureus; whereas using this extract, at the highest concentration $(50 \mathrm{mg} / \mathrm{mL}), 100 \%$ inhibition was observed for S. aureus and S. agalactiae.

In general, the dose of $\mathrm{PAB}$ required to obtain $50 \%$ of growth inhibition, was lower than that needed for the PEB. At concentrations of $12.5 \mathrm{mg} / \mathrm{mL}$, the PAB, reduced $50 \%$ the growth of E. coli, when extracted with PBS; and the growth of $S$. agalactiae, when extracted with PB. Additionally, $100 \%$ of growth reduction was observed for all the pathogenic strains, at doses of $50 \mathrm{mg} / \mathrm{mL}$, except for $S$. aureus in the case of the biosurfactant from L. paracasei extracted with PBS.

The antimicrobial activity of biosurfactants has sparked an increased interest in researchers and promoted additional efforts to further characterize these promising substances for biomedical, pharmaceutical, food or cosmetic applications. For instance, Sharma and Saharan [7] evaluated the antimicrobial ability of the glycolipid biosurfactant produced by Lactobacillus helveticus MRTL91 against E. coli (90\%), P. aeruginosa (76\%), S. aureus (92\%) or S. epidermidis $(98 \%)$ at $25 \mathrm{mg} / \mathrm{mL}$, observing a higher antimicrobial activity against $E$. coli and against $S$. epidermidis in comparison with the data observed in the current work.

Additionally, Gudiña and collaborators [6] showed that the glycoprotein biosurfactant from Lactobacillus agilis CCUG31450 inhibited the growth of S. aureus (20\%), P. aeruginosa $(13.5 \%)$ and $S$. agalactiae $(11 \%)$ at $5 \mathrm{mg} / \mathrm{mL}$, however it did not present an antimicrobial activity against $E$. coli and $C$. albicans under the same conditions. These results are in good agreement with the current study showing similar inhibitory capacities at $5 \mathrm{mg} / \mathrm{mL}$, for $S$. aureus, P. aeruginosa and $S$. agalactiae. Nevertheless, PAB and PEB 
extracts at similar concentrations as the ones used by Gudiña et al. [6] (5 mg/mL), showed slightly antimicrobial inhibition (less than 25\%) against E. coli and C. albicans. Furthermore, the same authors studied the antimicrobial properties of the glycoprotein biosurfactant produced by L. paracasei when grown in MRS Lac medium (standard MRS medium where glucose was replaced by lactose) [5,23]. Gudiña and co-workers [5] found a complete growth inhibition of E. coli, S. agalactiae and S. pyogenes at 25 $\mathrm{mg} / \mathrm{mL}$. Those growth inhibition values were slightly higher than those herein obtained using an extract produced by the same strain. However, it is important to notice that in the current work, a different biosurfactant was produced, namely a glycolipopeptide, as the strain was grown using glucose as carbon source, whereas Gudiña et al. [5] used lactose as carbon source.

It is well known that a same strain can produce different biosurfactants depending on the carbon source and fermenting conditions used [19,24-26]. For example, Singh et al. [25] reported that Bacillus amylofaciens strain AR2 could produce different types of surfactins depending on the carbon source used. In fact, the strain produced lipopeptides as a mixture of surfactin, iturin and fengycin when the minimal salt medium was supplemented with dextrose, sucrose and glycerol; whereas using maltose, lactose and sorbitol as carbon sources only iturin was produced.

Additionally, Shah et al. [27] evaluated different carbon sources (e.g. glucose, fructose, xylose, ribose, lactose, mannose, arabinose and galactose) for the production of sophorolipids and also studied their effect as antimicrobial agents. The authors suggested that the biosurfactant structures were different in the hydrophilic fraction (carbohydrate chain) but not in the hydrophobic side (fatty acid chain). The change on the carbon source led to different antibacterial activities. For instance, the sophorolipids produced when arabinose-containing medium was used were more effective against three of the four Gram-positive bacteria studied and against the Moraxella sp. (Gram-negative 
bacteria) as compared to the sophorolipids obtained when using glucose-based medium. Also, the sophorolipids obtained from cultures grown on arabinose showed no inhibition of the growth of E. coli; whereas the most effective sophorolipids against Bacillus subtilis was the ones obtained using lactose-based medium.

\subsection{Anti-adhesive activity}

Figure 5 to Figure 7 illustrate the anti-adhesive properties of biosurfactants from $L$. pentosus and from L. paracasei at concentrations up to $25 \mathrm{mg} / \mathrm{mL}$. Additionally, Table 2S (see in the supplementary information) summarizes the lowest concentration of biosurfactant extracts required to obtain anti-adhesive percentages of $50 \%$ and $100 \%$. Generally, the biosurfactants obtained from both Lactobacilli strains exhibited similar anti-adhesive activities. For instance, at $25 \mathrm{mg} / \mathrm{mL}$, biosurfactants produced by $L$. pentosus and extracted with PBS or PB inhibited around 63\%, $73 \%$ and $77 \%$ the highest adhesion of $P$. aeruginosa (Figure 5b), S. aureus (Figure 6a) and $S$. agalactiae (Figure 6c), respectively. Moreover, it was found that the biosurfactant from L. pentosus extracted with PB led to higher anti-adhesive activity against S. epidermidis (57\%) (Figure 6b) and S. pyogenes (69\%) (Figure 6d) comparing to those extracted with PBS (38\% and 52\%, respectively).

On the other hand, biosurfactants from L. paracasei extracted with PBS showed a more pronounced anti-adhesive effect on all the Gram-positive pathogens tested (such as $S$. aureus, S. epidermidis, S. agalactiae and S. pyrogenes) (Figure 6a to Figure 6d), and against $P$. aeruginosa (Gram-negative) comparing to the biosurfactants extracted with PB (Figure 5b). Furthermore, PAB inhibited the highest adhesion against $S$. agalactiae around $81 \%$ and $70 \%$ depending if the biosurfactant extracts were extracted with PBS or $\mathrm{PB}$, respectively (Figure 6c). 
Moreover, the inhibitory effect of all biosurfactant extracts (extracted with PBS and PB) on the adhesion of E. coli (Figure 5a) and C. albicans (Figure 7) was less than $30 \%$ at the highest concentration tested $(25 \mathrm{mg} / \mathrm{mL})$.

The anti-adhesive activity of biosurfactants is a relevant feature if their use as coatings of biomedical materials is envisaged. Indeed, many studies suggest that biosurfactants play an important role avoiding biofilm formation on different surfaces such as silicone rubber [28-30], titanium surface [31], polystyrene plates [32], among others. Sharma and Saharan [7] found that L. helveticus MRTL91, at $25 \mathrm{mg} / \mathrm{mL}$, considerably inhibited the adhesion of S. aureus (83\%) and S. epidermidis (85\%), although lower inhibitions were found for E. coli (50\%), P. aeruginosa (49\%) and C. albicans (data not provided). This poor inhibition obtained for E. coli and C. albicans was also found in the current study using the biosurfactant extracts obtained from L. pentosus and L. paracasei. However, the anti-adhesive capacities of the glycolipopeptide biosurfactants obtained from these strains against $P$. aeruginosa were slightly better (63\% and $72 \%$, respectively) in comparison with the glycolipid biosurfactant produced by L. helveticus.

Shokouhfard et al., [33] evaluated the anti-adhesive properties of a biosurfactant isolated from Lactobacillus acidophilus ATCC 4356 (biosurfactant composed by high protein content compared to other components such as polysaccharides and phosphates) on $S$. marcescens strains. The results showed good anti-adhesive activities, up to $60 \%$, for the different types of $S$. marcescens tested using $2.5 \mathrm{mg} / \mathrm{mL}$ of biosurfactant extract.

Gudiña et al. [6] showed that the glycoprotein biosurfactant from L. agilis CCUG31450 inhibited the adhesion of $S$. aureus around $60 \%$ at concentrations between 5 and 10 $\mathrm{mg} / \mathrm{mL}$ and around $50 \%$ at concentrations between 1 and $2.5 \mathrm{mg} / \mathrm{mL}$. The same behavior was observed for the glycolipopeptide biosurfactants used in the current work at the same concentrations (an anti-adhesion average of 64\%), except for the one produced by $L$. 
paracasei, extracted with PB and grown in glucose-based medium, that exhibited slightly lower values (less than $50 \%$ at $6.25 \mathrm{mg} / \mathrm{mL}$ ).

Madhu and Prapulla [34] evaluated a glycoprotein biosurfactant from Lactobacillus plantarum CFR 2194 that successfully inhibited the adhesion of S. aureus (67\%) at 25 $\mathrm{mg} / \mathrm{mL}$. It is important to notice that this inhibition was lower than the one herein obtained for glycolipopeptide biosurfactants from L. pentosus $(76 \%)$ and L. paracasei (72\%) both extracted with PBS.

In addition, Gudiña et al. [5] used $25 \mathrm{mg} / \mathrm{mL}$ of a glycoprotein biosurfactant from $L$. paracasei, grown on lactose and extracted with PBS, and found good anti-adhesive activities against $S$. aureus (72\%), S. epidermidis (62\%) and S. agalactiae (60\%), whereas a poor activity was observed for P. aeruginosa $(16.5 \%)$ and E. coli $(12 \%)$. Using the same concentration as Gudiña and co-workers [5], the glycolipopeptide biosurfactants from L. paracasei grown on glucose-based medium, showed higher antiadhesive properties against $S$. agalactiae (70-81\%), P. aeruginosa (57-72\%) depending if the biosurfactant extracts were extracted with PB or PBS respectively, and E. coli $(30 \%$ extracted with PBS and PB). In addition, in the case of S. aureus and S. epidermidis the results obtained in the current work (PAB in PBS) were similar to the anti-adhesive activity obtained by Gudiña et al. [5], being $72 \%$ and 55\%, respectively.

\section{CONCLUSIONS}

The cell-bound biosurfactants produced by L. pentosus, showed $100 \%$ of antimicrobial activity against $P$. aeruginosa (when extracted with PBS), S. aureus (when extracted with PB) and S. agalactiae (extracted with PBS or PB) at concentration of $50 \mathrm{mg} / \mathrm{mL}$. In the case of cell-bound biosurfactants produced by L. paracasei using both extraction methods, $100 \%$ of growth inhibition was found for all pathogens evaluated, except for $S$. aureus when extracted in PBS (83\%). 
Regarding the biosurfactants anti-adhesive activities, relevant values were obtained with all biosurfactant extracts evaluated against $P$. aeruginosa (between $57 \%$ for $\mathrm{PAB}$ extracted with PB to $72 \%$ for PAB extracted with PBS), S. aureus (between $60 \%$ for PAB extracted with PB to $76 \%$ for PEB extracted with PBS) and S. agalactiae (between $70 \%$ for $\mathrm{PAB}$ extracted with $\mathrm{PB}$ to $81 \%$ for $\mathrm{PAB}$ extracted with $\mathrm{PBS})$. However, for $E$. coli and C. albicans these values were lower than $30 \%$.

Based on the results herein gathered, it can be speculated that small changes in the carbohydrates, lipids and proteins percentages, of the polymeric fraction of biosurfactants, can play an important role on their biological activities and accordingly on their applications in the cosmetic industry.

\section{ACKNOWLEDGMENTS}

This study was supported by the Portuguese Foundation for Science and Technology (FCT) under the scope of the strategic funding of UID/BIO/04469/2013 unit, COMPETE 2020 (POCI-01-0145-FEDER-006684), the Project MultiBiorefinery - Multipurposestrategies for broadband agro-forest and fisheries by-products valorisation: a step forward for a truly integrated biorefinery (POCI-01-0145-FEDER-016403) and the project RECI/BBB-EBI/0179/2012 (FCOMP-01-0124-FEDER-027462), as well as X. Vecino post-doctoral grant (SFRH/BPD/101476/2014). Also, L. Rodríguez-López acknowledges to the Spanish Ministry of Education, Culture and Sport for her predoctoral fellowship (FPU15/00205).

\section{REFERENCES}

[1] R.A. Bojar, K.T. Holland, Review: the human cutaneous microflora and factors controlling colonization, World J. Microb. Biot. 18 (2002) 889-903. 
[2] A.L. Cogen, V. Nizet, R.L. Gallo, Skin microbiota: a source of disease or defence?, Brit. J. Dermatol. 158 (2008) 442-455.

[3] R.J. Bertelsen, M.P. Longnecker, M. Løvik, A.M. Calafat, K.H. Carlsen, S.J. London, K.C. Lødrup Carlsen, Triclosan exposure and allergic sensitization in Norwegian children, Allergy: Eur. J. Allergy Clin. Immunol. 68 (2013) 84-91.

[4] C.A. Giuliano, M.J. Rybak, Efficacy of triclosan as an antimicrobial hand soap and its potential impact on antimicrobial resistance: A focused review, Pharmacotherapy 35 (2015) 328-336.

[5] E.J. Gudiña, J.A. Teixeira, L.R. Rodrigues, Isolation and functional characterization of a biosurfactant produced by Lactobacillus paracasei, Colloids Surface. B. 76 (2010) 298-304.

[6] E.J. Gudiña, E.C. Fernandes, J.A. Teixeira, L.R. Rodrigues, Antimicrobial and antiadhesive activities of cell-bound biosurfactant from Lactobacillus agilis CCUG31450, RSC Adv. 5 (2015) 90960-90968.

[7] D. Sharma, B.S. Saharan, Functional characterization of biomedical potential of biosurfactant produced by Lactobacillus helveticus, Biotechnol. Rep. 11 (2016) $27-35$.

[8] M. Bouassida, N. Fourati, F. Krichen, R. Zouari, S. Ellouz-Chaabouni, D. Ghribi, Potential application of Bacillus subtilis SPB1 lipopeptides in toothpaste formulation, J. Adv. Res. 8 (2017) 425-433.

[9] Vecino, X., Cruz, J.M., Moldes, A.B., L.R. Rodrigues, Biosurfactants in cosmetic formulations: trends and challenges, Crit. Rev. Biotechnol. 37 (2017) 911-923. 
[10] A. Ferreira, X. Vecino, D. Ferreira, J.M. Cruz, A.B. Moldes, L.R. Rodrigues, Novel cosmetic formulations containing a biosurfactant from Lactobacillus paracasei, Colloid. Surf. B-Biointerfaces 155 (2017) 522-529.

[11] E.J. Gudiña, V. Rangarajan, R. Sen, L.R. Rodrigues, Potential therapeutic applications of biosurfactants, Trends Pharmacol. Sci. 34 (2013) 667-675.

[12] K. Desanto, Rhamnolipid-based formulations, Patent WO 2008013899 A2, 2008.

[13] T. Bujak, T. Wasilewski, Z., Nizioł-Łukaszewska, Role of macromolecules in the safety of use of body wash cosmetics, Colloid. Surface. B-Biointerfaces 135 (2015) 497-503.

[14] T. Stipcevic, C.P. Knight, T.E. Kippin, Stimulation of adult neural stem cells with a novel glycolipid biosurfactant, Acta Neurol. Belg. 113 (2013) 501-506.

[15] V.A. Pashynska, Mass spectrometric study of rhamnolipid biosurfactants and their interactions with cell membrane phospholipids, Biopolymers Cell 25 (2009) 504508.

[16] X. Vecino, R. Devesa-Rey, J.M. Cruz, A.B. Moldes, Study of the synergistic effects of salinity, $\mathrm{pH}$, and temperature on the surface-active properties of biosurfactants produced by Lactobacillus pentosus, J. Agr. Food Chem. 60 (2012) 1258-1265.

[17] X. Vecino, G. Bustos, R. Devesa-Rey, J.M. Cruz, A.B. Moldes, Salt-free aqueous extraction of a cell-bound biosurfactant: A kinetic study, J. Surfactants Deterg. 18 (2015) 267-274.

[18] X. Vecino, L. Barbosa-Pereira, R. Devesa-Rey, J.M. Cruz, A.B. Moldes, Optimization of extraction conditions and fatty acid characterization of Lactobacillus pentosus cell-bound biosurfactant/bioemulsifier, J. Sci. Food Agric. 95 (2015) 313-320. 
[19] X. Vecino, L. Rodríguez-López, E.J. Gudiña, J.M. Cruz, A.B. Moldes, L.R Rodrigues, Vineyard pruning waste as an alternative carbon source to produce novel biosurfactants by Lactobacillus paracasei, J. Ind. Eng. Chem. 55 (2017) $40-49$.

[20] M. Dubois, K.A. Gilles, J.K. Hamilton, P.A. Rebers, F. Smith, Colorimetric method for determination of sugars and related substances, Anal. Chem. 28 (1956) 350356.

[21] F. Mariotti, D. Tomé, P.P. Mirand, Converting nitrogen into protein-beyond 6.25 and Jones' factos, Crit. Rev. Food Sci. 48 (2008) 177-184.

[22] L.R. Rodrigues, I.M. Banat, J.A. Teixeira, R. Oliveira, Biosurfactants: Potential applications in medicine, J. Antimicrob. Chemoth. 57 (2006) 609-618.

[23] E.J. Gudiña, V. Rocha, J.A. Teixeira, L.R. Rodrigues, Antimicrobial and antiadhesive properties of a biosurfactant isolated from Lactobacillus paracasei ssp. paracasei A20, Lett. Appl. Microbiol. 50 (2010) 419-424.

[24] Saikia, R.R., Deka, S., Deka, M., Banat, I.M. Isolation of biosurfactant-producing Pseudomonas aeruginosa RS29 from oil-contaminated soil and evaluation of different nitrogen sources in biosurfactant production, Annal. Microbiol. 62 (2012) 753-763.

[25] A.K. Singh, R. Rautela, S.S. Cameotra, Substrate dependent in vitro antifungal activity of Bacillus sp strain AR2. Microb. Cell Fact. 13 (2014) 2-11.

[26] N.M.P. Rocha e Silva, R.D. Rufino, J.M. Luna, V.A. Santos, L.A. Sarubbo, Screening of Pseudomonas species for biosurfactant production using low-cost substrates, Biocatal. Agr. Biotechnol. 3 (2014) 132-139. 
[27] V. Shah, D. Badia, Sophorolipids Having Enhanced Antibacterial Activity, Antimicrob. Agents Chemother. 51 (2007) 397-400.

[28] L. Rodrigues, H.C. Van Der Mei, J.A. Teixeira, R. Oliveira, Influence of biosurfactants from probiotic bacteria on formation of biofilms on voice prostheses, Appl. Environ. Microb. 70 (2004) 4408-4410.

[29] L. Rodrigues, H. Van Der Mei, J.A. Teixeira, R. Oliveira, Biosurfactant from Lactococcus lactis 53 inhibits microbial adhesion on silicone rubber, Appl. Microbiol. Biot. 66 (2004) 306-311.

[30] C. Ceresa, F. Tessarolo, I. Caola, G. Nollo, M. Cavallo, M. Rinaldi, L. Fracchia, Inhibition of Candida albicans adhesion on medical-grade silicone by a Lactobacillus-derived biosurfactant, J. Appl. Microbiol. 118 (2015) 1116-1125.

[31] E. Ciandrini, R. Campana, L. Casettari, D.R. Perinelli, L. Fagioli, A. Manti, G.F. Palmieri, S. Papa, W. Baffone, Characterization of biosurfactants produced by Lactobacillus spp. and their activity against oral streptococci biofilm, Appl. Microbiol. Biotechnol. 100 (2016) 6767-6777.

[32] N.C Gómez, J.M.P. Ramiro, B.X.V. Quecan, B.D.G. de Melo Franco, Use of potential probiotic lactic acid bacteria (LAB) biofilms for the control of Listeria monocytogenes, Salmonella Typhimurium, and Escherichia coli O157: H7 biofilms formation, Front. Microbiol. 7 (2016) 1-15.

[33] M. Shokouhfard, R. Kasra Kermanshahi, R. Vahedi Shahandashti, M.M. Feizabadi, S.Teimourian, The inhibitory effect of a Lactobacillus acidophilus derived biosurfactant on Serratia marcescens biofilm formation, Iran. J. Basic Med. Sci. 18 (2015) 1001-1007. 
[34] A.N. Madhu, S.G. Prapulla, Evaluation and functional characterization of a biosurfactant produced by Lactobacillus plantarum CFR 2194, Appl. Biochem. Biotech. 172 (2014) 1777-1789. 
a)

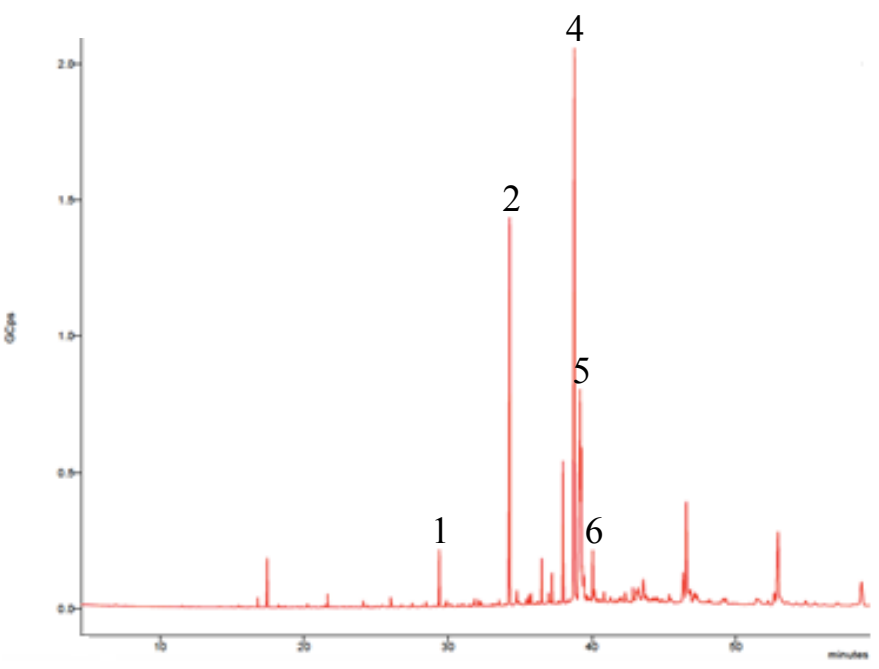

c)

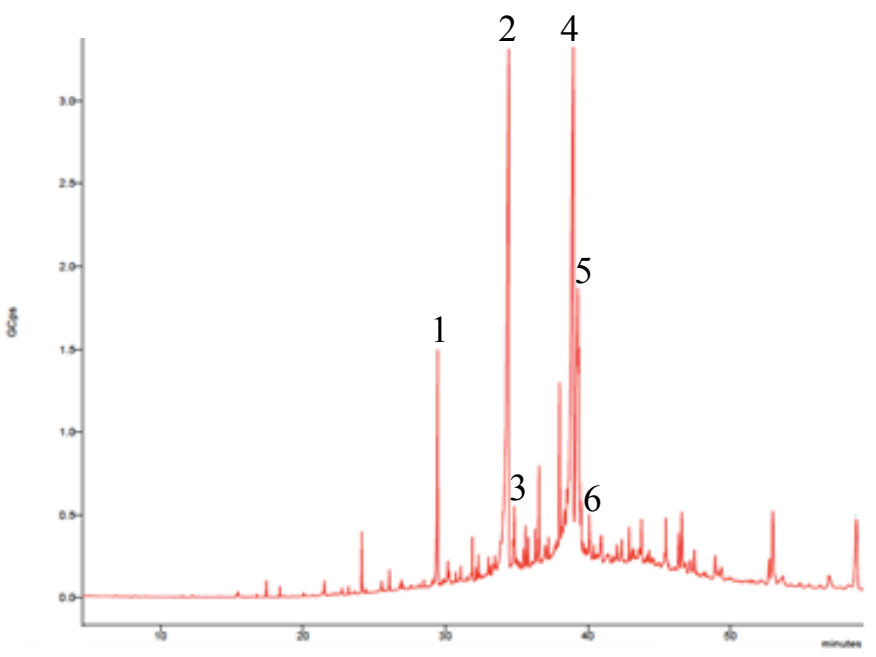

b)

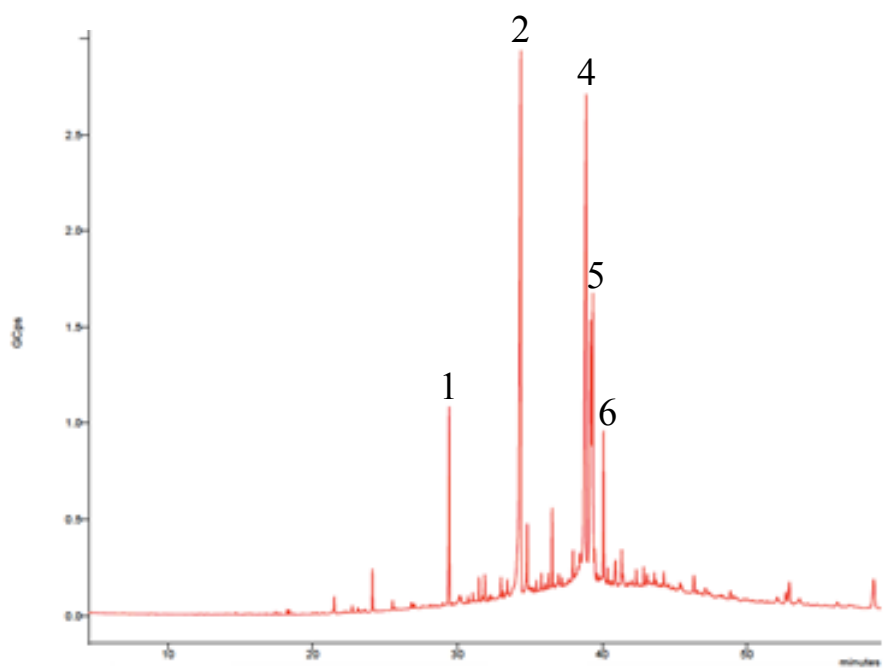

d)

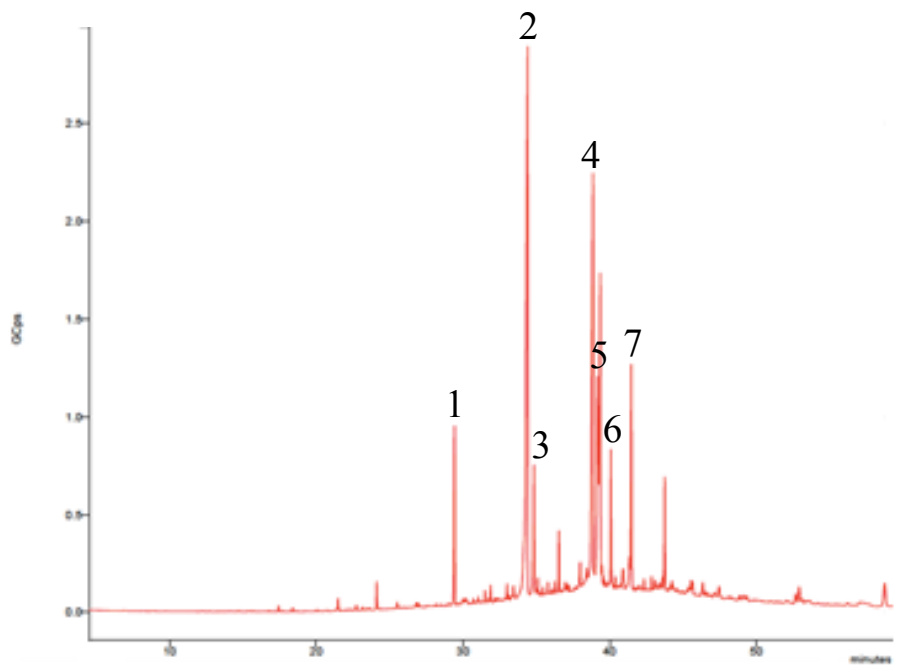

Figure 1. Fatty acids profile of the biosurfactants produced by Lactobacillus pentosus (a, b) and Lactobacillus paracasei (c, d) extracted using phosphate buffer saline (PBS) (a, c) and phosphate buffer $(\mathrm{PB})(\mathrm{b}, \mathrm{d})$ respectively. The numbers denote the major relative fatty acids in the biosurfactants extracts as follows: $1=$ myristic acid (methyl ester); $2=$ palmitic acid; $3=$ palmitoleic acid; $4=$ stearic acid, $5=$ oleic acid, $6=$ linoleic acid, $7=\alpha-$ linoleic acid. 


\section{E coli}

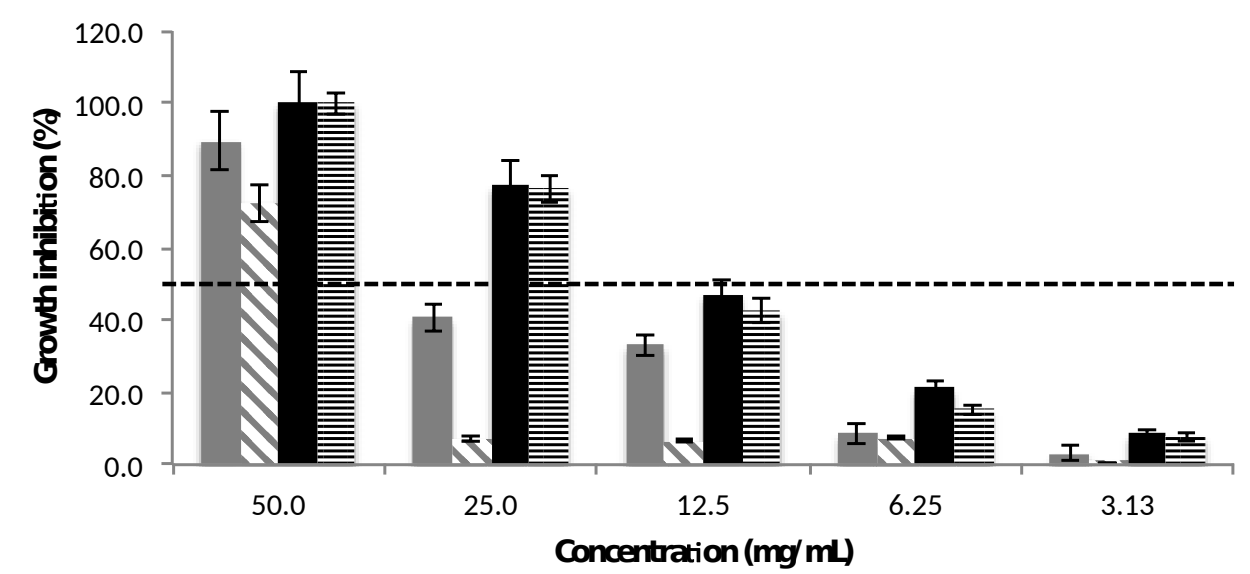

\section{P. aenuginosa}

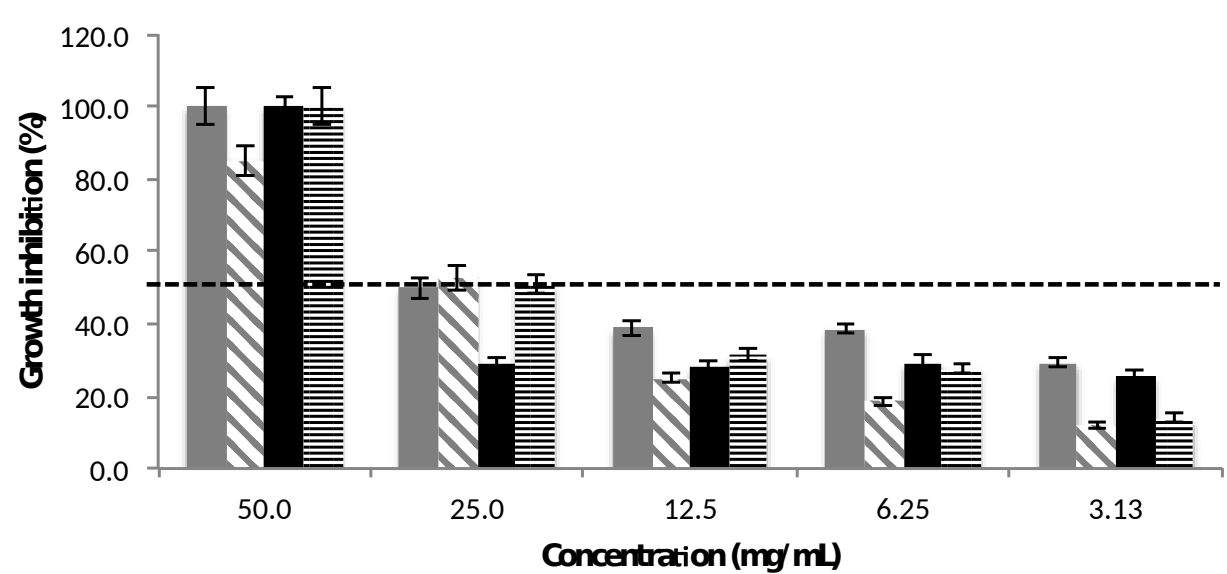

Figure 2. Antimicrobial activity of the biosurfactants produced by Lactobacillus pentosus (PEB) and Lactobacillus paracasei (PAB) against Gramnegative microorganisms. PEB and PAB were extracted using phosphate buffer saline (PBS) and phosphate buffer (PB) respectively ( $\square$ PEB in PBS; $N$ PEB in PB; $\square$ PAB in PBS; 豆 PAB in PB). The results represent the average of triplicate experiments \pm standard deviation. 


\section{S aureus}

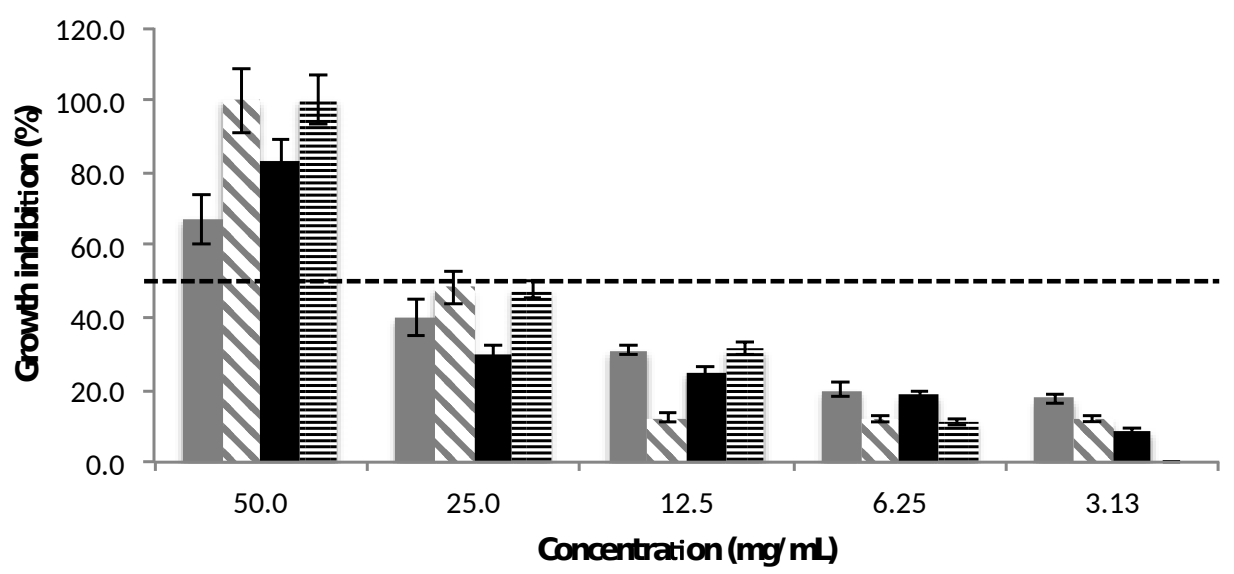

\section{S. epidermidis}

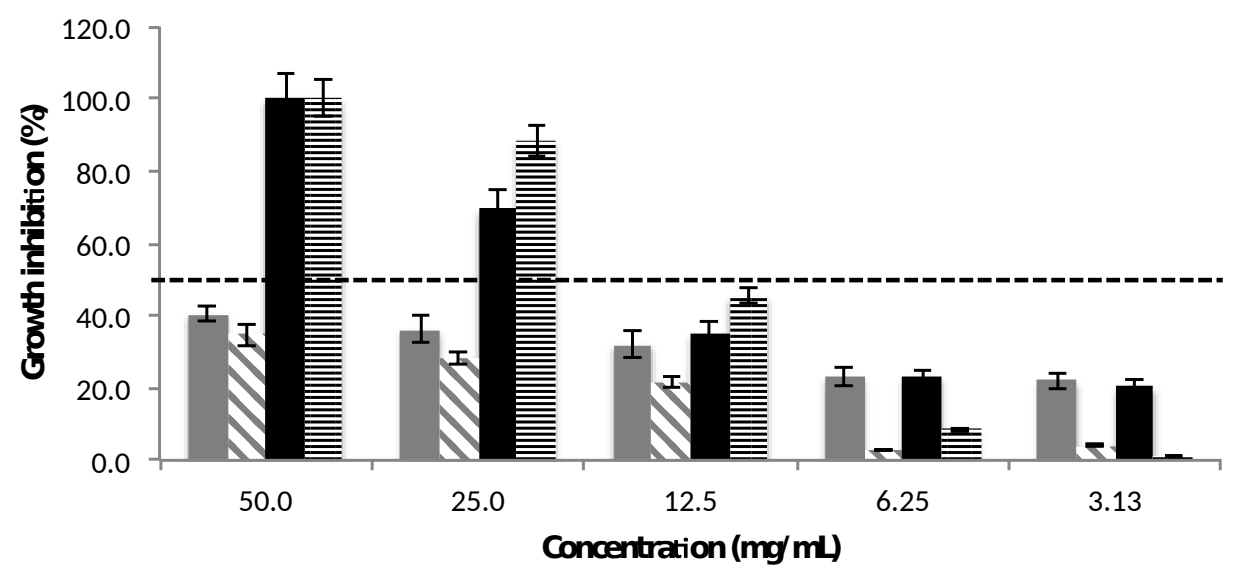

Figure 3. Antimicrobial activity of the biosurfactants produced by Lactobacillus pentosus (PEB) and Lactobacillus paracasei (PAB) against Grampositive microorganisms. PEB and PAB were extracted using phosphate buffer saline (PBS) and phosphate buffer (PB) respectively ( $\square$ PEB in PBS; N PEB in PB; $\square$ PAB in PBS; 豆 PAB in PB). The results represent the average of triplicate experiments \pm standard deviation. 


\section{S. agalaciae}

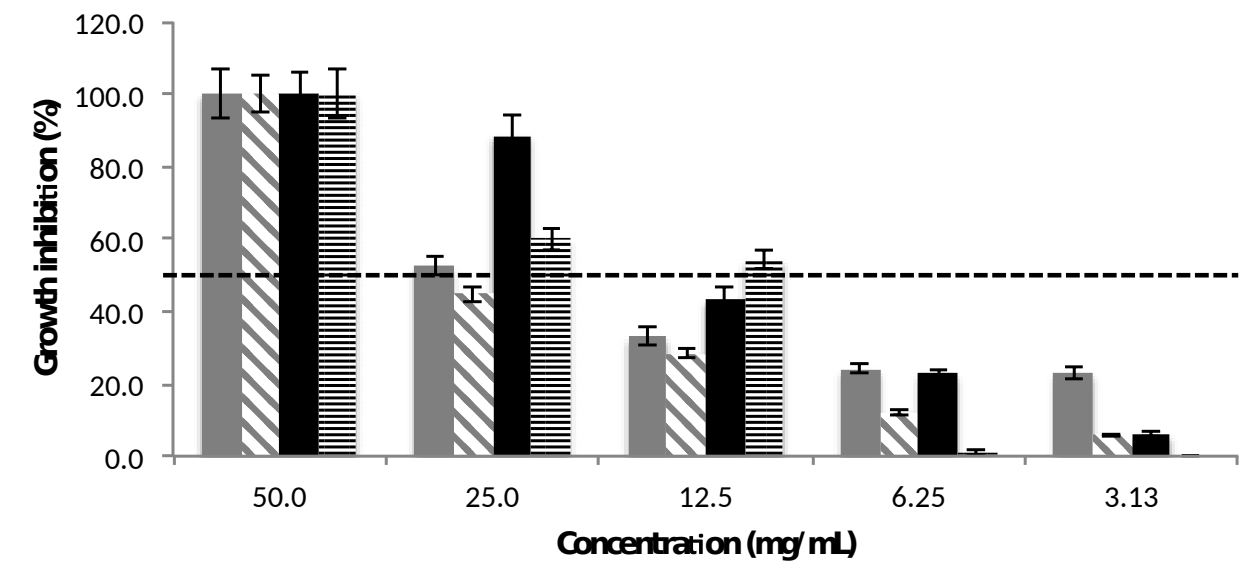

\section{S. pyogenes}

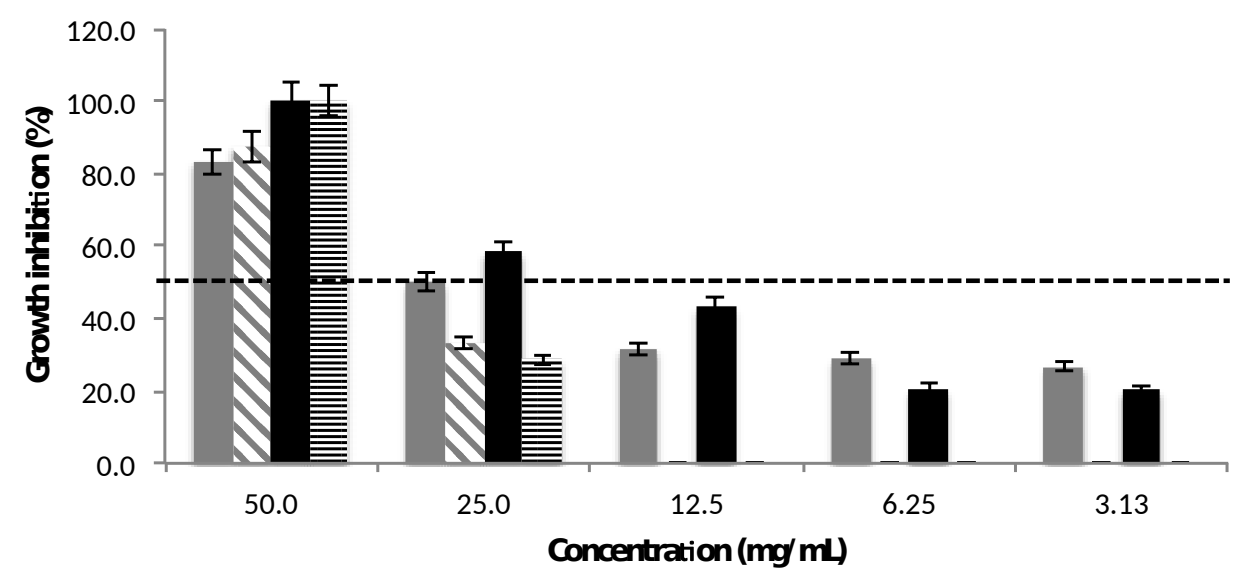

Figure 3 (Continuation). Antimicrobial activity of the biosurfactants produced by Lactobacillus pentosus (PEB) and Lactobacillus paracasei (PAB) against Gram-positive microorganisms. PEB and PAB were extracted using phosphate buffer saline (PBS) and phosphate buffer (PB) respectively ( $\mathrm{PEB}$ in PBS; N PEB in PB; $\square \mathrm{PAB}$ in PBS; 豆 PAB in PB). The results represent the average of triplicate experiments \pm standard deviation. 


\section{C albicans}

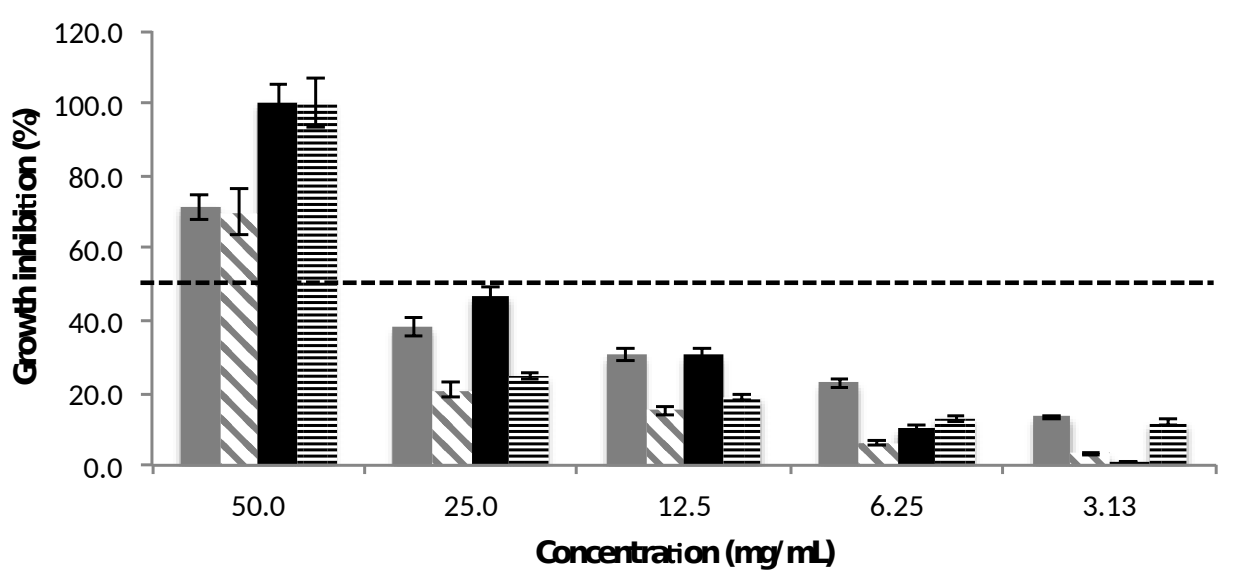

Figure 4. Antimicrobial activity of the biosurfactants produced by Lactobacillus pentosus (PEB) and Lactobacillus paracasei (PAB) against fungi microorganisms. PEB and PAB were extracted using phosphate buffer saline (PBS) and phosphate buffer (PB) respectively ( $\square$ PEB in PBS; $N$

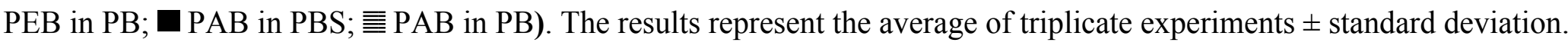




\section{E coli}

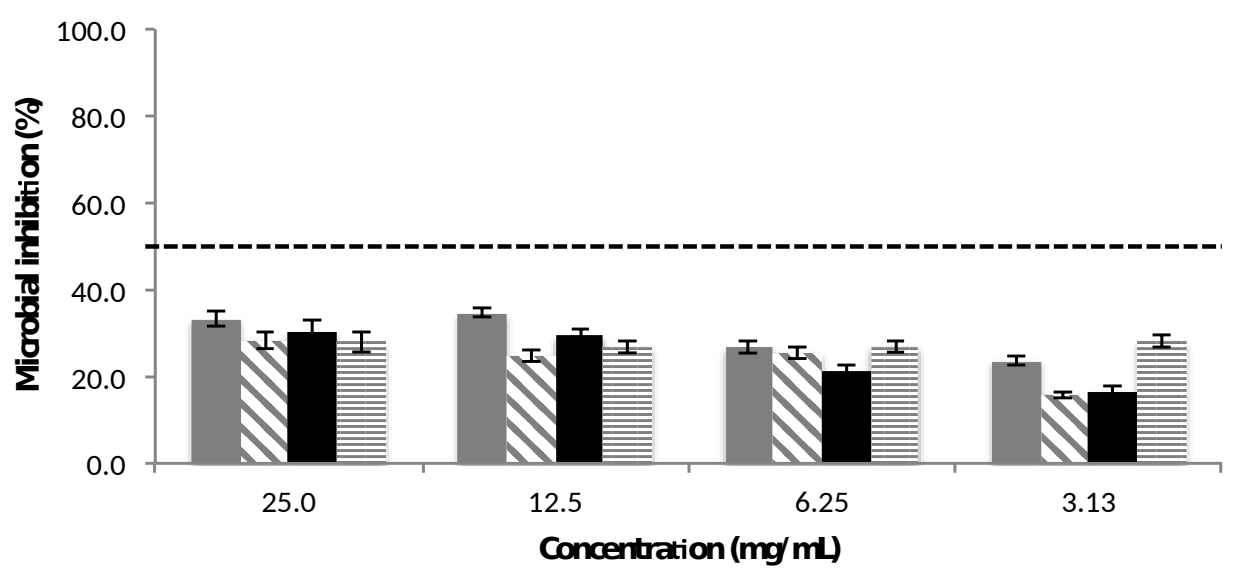

\section{P. aenuginosa}

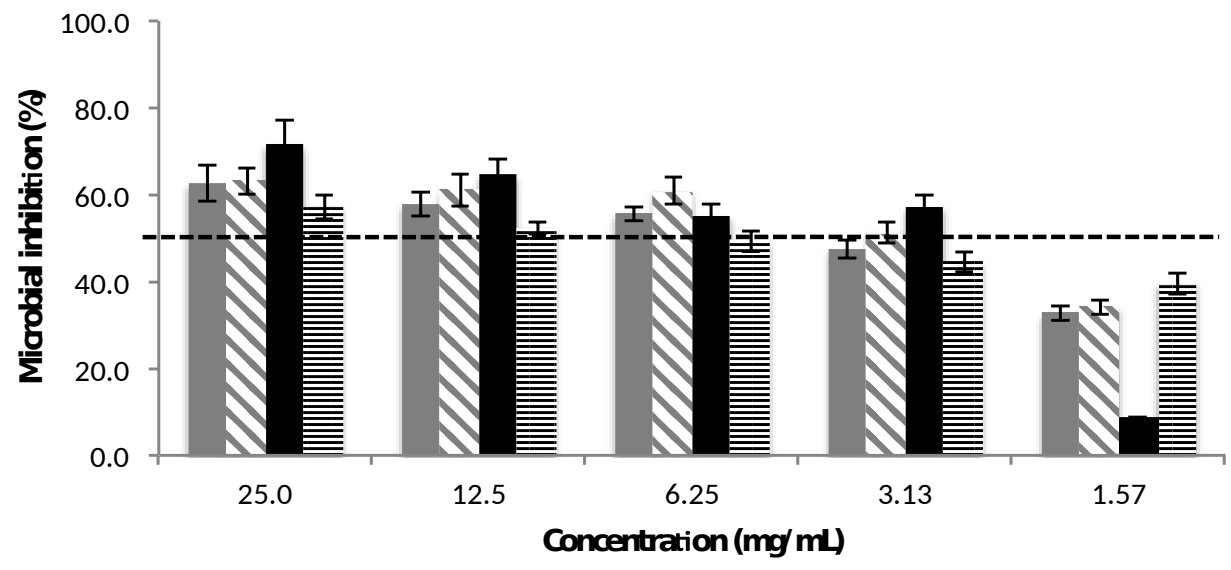

Figure 5. Anti-adhesive activity of the biosurfactants produced by Lactobacillus pentosus (PEB) and Lactobacillus paracasei (PAB) against Gramnegative microorganisms. PEB and PAB were extracted using phosphate buffer saline (PBS) and phosphate buffer (PB) respectively ( $\square$ PEB in PBS; $N$ PEB in PB; $\square$ PAB in PBS; 豆 PAB in PB). The results represent the average of triplicate experiments \pm standard deviation. 


\section{S aureus}

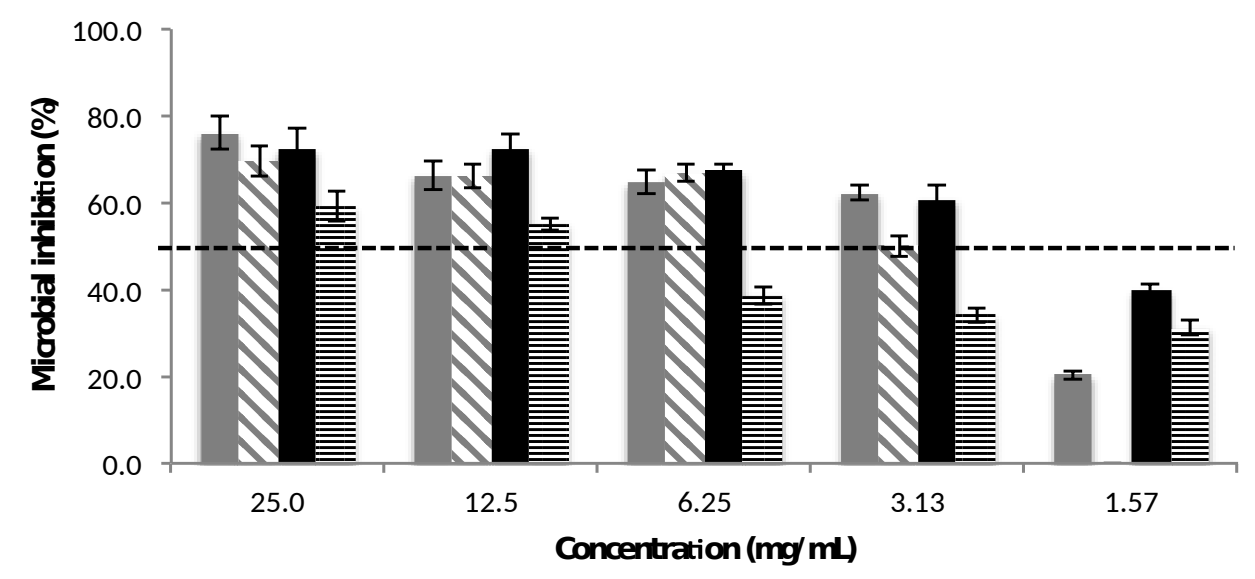

\section{S. epidermidis}

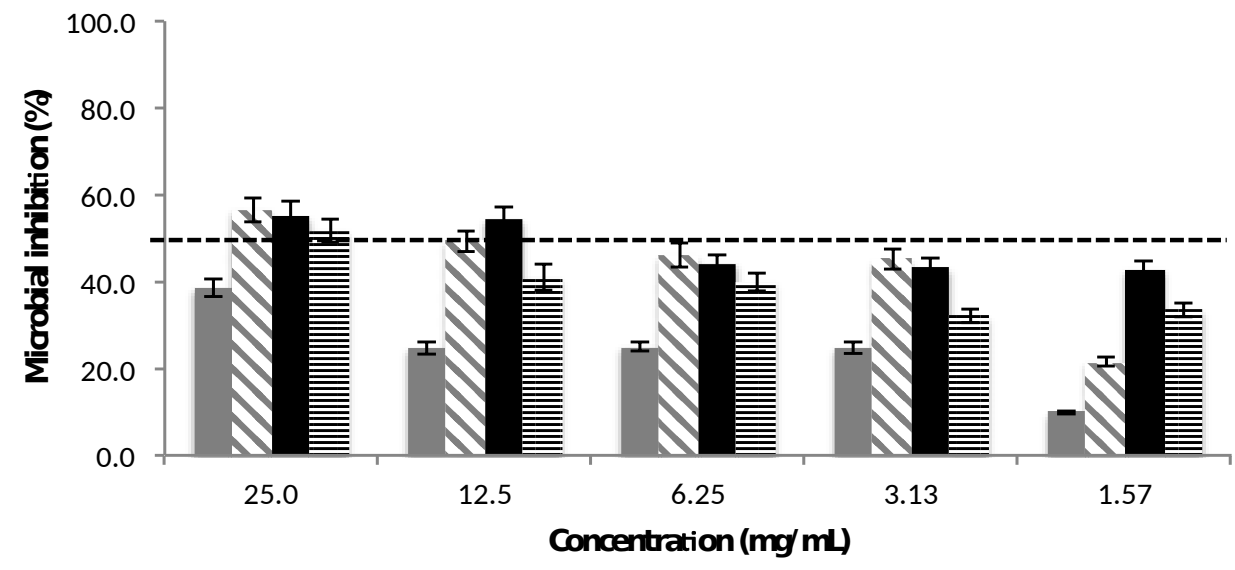

Figure 6. Anti-adhesive activity of the biosurfactants produced by Lactobacillus pentosus (PEB) and Lactobacillus paracasei (PAB) against Grampositive microorganisms. PEB and PAB were extracted using phosphate buffer saline (PBS) and phosphate buffer (PB) respectively ( $\square$ PEB in PBS;

N PEB in PB; $\square$ PAB in PBS; 豆 PAB in PB). The results represent the average of triplicate experiments \pm standard deviation. 


\section{S. agalaciae}

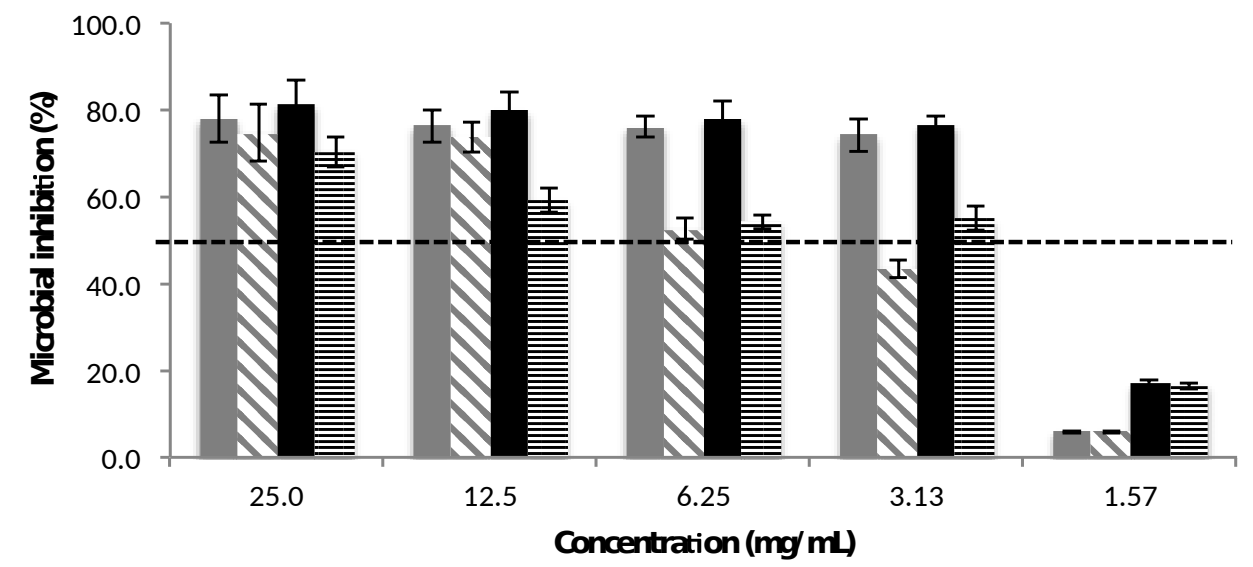

\section{S pyogenes}

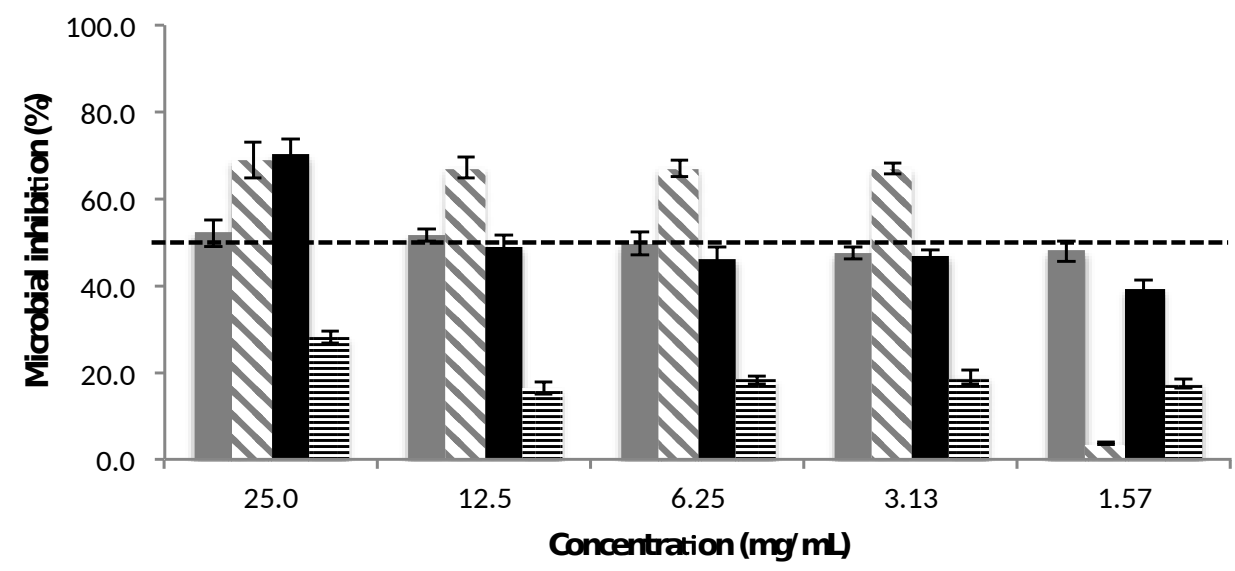

Figure 6 (Continuation). Anti-adhesive activity of the biosurfactants produced by Lactobacillus pentosus (PEB) and Lactobacillus paracasei (PAB) against Gram-positive microorganisms. PEB and PAB were extracted using phosphate buffer saline (PBS) and phosphate buffer (PB) respectively ( PEB in PBS; . N PEB in PB; $\mathbf{D A B}$ in PBS; 豆 PAB in PB). The results represent the average of triplicate experiments \pm standard deviation. 


\section{C albicans}

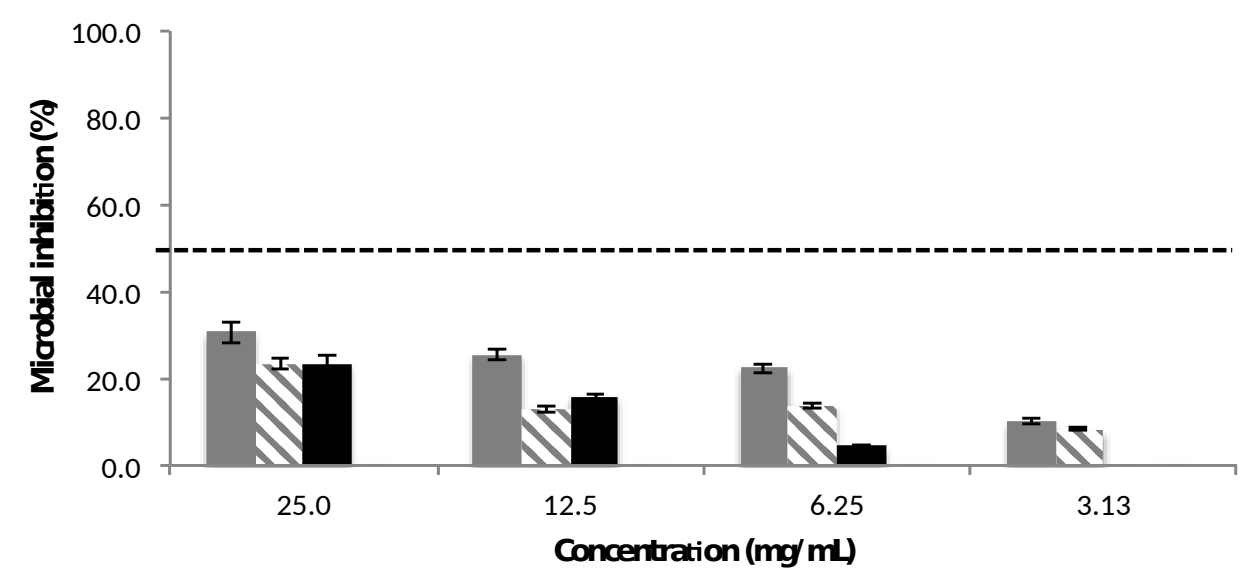

Figure 7. Anti-adhesive activity of the biosurfactants produced by Lactobacillus pentosus (PEB) and Lactobacillus paracasei (PAB) against fungi microorganisms. PEB and PAB were extracted using phosphate buffer saline (PBS) and phosphate buffer (PB) respectively ( $\square$ PEB in PBS; $N$ PEB in $\mathrm{PB}$; $\mathrm{PAB}$ in $\mathrm{PBS}$; 豆 $\mathrm{PAB}$ in $\mathrm{PB})$. The results represent the average of triplicate experiments \pm standard deviation. 
TABLE 1. Chemical composition and surfactant properties of the cell-bound biosurfactants produced by the Lactobacilli strains under study.

\begin{tabular}{|l|c|c|c|c|}
\hline Cell-bound biosurfactant & PEB in PBS & PEB in PB & PAB in PBS & PAB in PB \\
\hline CMC (mg/mL) & $1.26 \pm 0.11$ & $0.81 \pm 0.08$ & $1.35 \pm 0.13$ & $1.26 \pm 0.11$ \\
\hline ST reduction (mN/m) & $19.2 \pm 0.57$ & $19.7 \pm 0.22$ & $25.1 \pm 0.49$ & $20.9 \pm 0.41$ \\
\hline Protein content (\%) & $12.6 \pm 1.07$ & $30.7 \pm 1.54$ & $21.19 \pm 0.18$ & $58.22 \pm 3.14$ \\
\hline Carbohydrate content (\%) & $7.7 \pm 0.57$ & $19.5 \pm 1.17$ & $5.47 \pm 1.19$ & $14.24 \pm 3.81$ \\
\hline Lipid content (\%) & $50.5 \pm 2.27$ & $41.8 \pm 2.51$ & $24.40 \pm 1.15$ & $13.66 \pm 1.22$ \\
\hline
\end{tabular}

PEB and PAB: biosurfactants produced by L. pentosus and L. paracasei and extracted using phosphate buffer saline (PBS) and phosphate buffer $(\mathrm{PB})$ respectively. 


\section{Supplementary information}

for

Bioactivity of glycolipopeptide cell-bound biosurfactants against skin pathogens

Vecino, X. ${ }^{1,2 *}$, Rodríguez-López, L. ${ }^{2}$, Ferreira, D. ${ }^{1}$, Cruz, J.M. ${ }^{2}$, Moldes, A.B. ${ }^{2}$, Rodrigues, L.R. ${ }^{1}$

${ }^{1}$ CEB-Centre of Biological Engineering, University of Minho, 4710-057 Braga, Portugal.

${ }^{2}$ Chemical Engineering Department, School of Industrial Engineering (EEI)- Módulo Tecnológico Industrial (MTI), University of Vigo, Campus As Lagoas-Marcosende, 36310 Vigo, Spain.

*Author corresponding: xanel.vecino@,ceb.uminho.pt; xanel.vecino@uvigo.es. 
TABLE 1S. Biosurfactant concentration that led to $50 \%$ and $100 \%$ of growth inhibition between the values assayed.

\begin{tabular}{|c|c|c|c|c|}
\hline \multirow[b]{2}{*}{ Microorganisms } & \multicolumn{2}{|c|}{$P E B$ in $P B S$} & \multicolumn{2}{|c|}{ PEB in PB } \\
\hline & $\begin{array}{c}\text { Dose to achieve } 50 \% \\
\text { growth inhibition }(\mathrm{mg} / \mathrm{mL})\end{array}$ & $\begin{array}{l}\text { Dose to achieve } 100 \% \\
\text { growth inhibition }(\mathrm{mg} / \mathrm{mL})\end{array}$ & $\begin{array}{c}\text { Dose to achieve } 50 \% \\
\text { growth inhibition }(\mathrm{mg} / \mathrm{mL})\end{array}$ & $\begin{array}{l}\text { Dose to achieve } 100 \% \\
\text { growth inhibition }(\mathrm{mg} / \mathrm{mL})\end{array}$ \\
\hline \multicolumn{5}{|c|}{ Gram-negative pathogens } \\
\hline E. coli & 50 & ND & 50 & ND \\
\hline P. aeruginosa & 25 & 50 & 25 & ND \\
\hline \multicolumn{5}{|c|}{ Gram-positive pathogens } \\
\hline S. aureus & 50 & ND & 25 & 50 \\
\hline S. epidermidis & ND & ND & ND & ND \\
\hline S. agalactiae & 25 & 50 & 50 & 50 \\
\hline S. pyogenes & 25 & ND & 50 & ND \\
\hline \multicolumn{5}{|l|}{ Fungi } \\
\hline \multirow[t]{3}{*}{ C. albicans } & 50 & ND & 50 & ND \\
\hline & \multicolumn{2}{|c|}{$\mathbf{P A B}$ in $\mathbf{P B S}$} & \multicolumn{2}{|c|}{$\mathbf{P A B}$ in $\mathbf{P B}$} \\
\hline & $\begin{array}{c}\text { Dose to achieve } 50 \% \\
\text { growth inhibition }(\mathrm{mg} / \mathrm{mL})\end{array}$ & $\begin{array}{c}\text { Dose to achieve } 100 \% \\
\text { growth inhibition }(\mathrm{mg} / \mathrm{mL})\end{array}$ & $\begin{array}{c}\text { Dose to achieve } 50 \% \\
\text { growth inhibition }(\mathrm{mg} / \mathrm{mL})\end{array}$ & $\begin{array}{l}\text { Dose to achieve } 100 \% \\
\text { growth inhibition }(\mathrm{mg} / \mathrm{mL})\end{array}$ \\
\hline \multicolumn{5}{|c|}{ Gram-negative pathogens } \\
\hline E. coli & 12.5 & 50 & 25 & 50 \\
\hline P. aeruginosa & 50 & 50 & 25 & 50 \\
\hline \multicolumn{5}{|c|}{ Gram-positive pathogens } \\
\hline S. aureus & 50 & ND & 25 & 50 \\
\hline S. epidermidis & 25 & 50 & 25 & 50 \\
\hline S. agalactiae & 25 & 50 & 12.5 & 50 \\
\hline S. pyogenes & 25 & 50 & 50 & 50 \\
\hline \multicolumn{5}{|l|}{ Fungi } \\
\hline C. albicans & 25 & 50 & 50 & 50 \\
\hline
\end{tabular}

ND: not inhibition at the concentrations assayed; PEB and PAB: biosurfactants produced by L. pentosus and L. paracasei and extracted using phosphate buffer saline (PBS) and phosphate buffer $(\mathrm{PB})$ respectively. 
TABLE 2S. Biosurfactant concentration that gave $50 \%$ or $100 \%$ of anti-adhesive capacity between the values assayed.

\begin{tabular}{|c|c|c|c|c|}
\hline \multirow[b]{2}{*}{ Microorganisms } & \multicolumn{2}{|c|}{ PEB in PBS } & \multicolumn{2}{|c|}{ PEB in PB } \\
\hline & $\begin{array}{c}\text { Dose to achieve } 50 \% \\
\text { microbial inhibition }(\mathrm{mg} / \mathrm{mL})\end{array}$ & $\begin{array}{c}\text { Dose to achieve } 100 \% \\
\text { microbial inhibition }(\mathrm{mg} / \mathrm{mL})\end{array}$ & $\begin{array}{c}\text { Dose to achieve } 50 \% \\
\text { microbial inhibition }(\mathrm{mg} / \mathrm{mL})\end{array}$ & $\begin{array}{l}\text { Dose to achieve } 100 \% \text { growth } \\
\text { inhibition }(\mathrm{mg} / \mathrm{mL})\end{array}$ \\
\hline \multicolumn{5}{|c|}{ Gram-negative pathogens } \\
\hline E. coli & ND & ND & ND & ND \\
\hline P. aeruginosa & 3.13 & ND & 3.13 & ND \\
\hline \multicolumn{5}{|c|}{ Gram-positive pathogens } \\
\hline S. aureus & 3.13 & ND & 3.13 & ND \\
\hline S. epidermidis & ND & ND & 6.25 & ND \\
\hline S. agalactiae & 3.13 & ND & 6.25 & ND \\
\hline S. pyogenes & 1.57 & ND & 3.13 & ND \\
\hline \multicolumn{5}{|l|}{ Fungi } \\
\hline \multirow{3}{*}{ C. albicans } & ND & ND & ND & ND \\
\hline & \multicolumn{2}{|c|}{$\mathbf{P A B}$ in $\mathbf{P B S}$} & \multicolumn{2}{|c|}{$\mathbf{P A B}$ in $\mathbf{P B}$} \\
\hline & $\begin{array}{c}\text { Dose to achieve } 50 \% \\
\text { microbial inhibition }(\mathrm{mg} / \mathrm{mL})\end{array}$ & $\begin{array}{c}\text { Dose to achieve } 100 \% \\
\text { microbial inhibition }(\mathrm{mg} / \mathrm{mL})\end{array}$ & $\begin{array}{c}\text { Dose to achieve } 50 \% \\
\text { microbial inhibition }(\mathrm{mg} / \mathrm{mL})\end{array}$ & $\begin{array}{c}\text { Dose to achieve } 100 \% \\
\text { microbial inhibition }(\mathrm{mg} / \mathrm{mL})\end{array}$ \\
\hline \multicolumn{5}{|c|}{ Gram-negative pathogens } \\
\hline E. coli & ND & ND & ND & ND \\
\hline P. aeruginosa & 3.13 & ND & 6.25 & ND \\
\hline \multicolumn{5}{|c|}{ Gram-positive pathogens } \\
\hline S. aureus & 3.13 & ND & 12.5 & ND \\
\hline S. epidermidis & 12.5 & ND & 25 & ND \\
\hline S. agalactiae & 3.13 & ND & 3.13 & ND \\
\hline S. pyogenes & 6.25 & ND & ND & ND \\
\hline \multicolumn{5}{|l|}{ Fungi } \\
\hline C. albicans & ND & ND & ND & ND \\
\hline
\end{tabular}

ND: not inhibition at the concentrations assayed; PEB and PAB: biosurfactants produced by L. pentosus and L. paracasei and extracted using phosphate buffer saline (PBS) and phosphate buffer $(\mathrm{PB})$ respectively. 